\title{
Inducible Nitric Oxide Synthase Polymorphisms and Nitric Oxide Levels in Individuals with Chronic Periodontitis
}

\author{
Raquel M. Scarel-Caminaga ${ }^{1, *}$, Flávia F. Cera ${ }^{1}$, Suzane C. Pigossi ${ }^{2}$, Livia S. Finoti ${ }^{3}$, \\ Yeon J. Kim ${ }^{4}$, Aline C. Viana ${ }^{2}$, Rodrigo Secolin ${ }^{5}$, Marcelo F. Montenegro ${ }^{6}$, \\ José E. Tanus-Santos ${ }^{6}$, Silvana R. P. Orrico ${ }^{2}$ and Joni A. Cirelli ${ }^{2}$ \\ 1 Department of Morphology, School of Dentistry at Araraquara, São Paulo State University (UNESP), \\ Humaita St., 1680, Araraquara CEP 14801-903, São Paulo, Brazil; flaviafcera@gmail.com \\ 2 Department of Diagnosis and Surgery, School of Dentistry at Araraquara, São Paulo State \\ University (UNESP), Humaita St., 1680, Araraquara CEP 14801-903, São Paulo, Brazil; \\ supigossi@ymail.com (S.C.P.); dentistaaline@yahoo.com.br (A.C.V.); s-orrico@foar.unesp.br (S.R.P.O.); \\ cirrelli@foar.unesp.br (J.A.C.) \\ 3 Department of Periodontics, School of Dental Medicine, University of Pennsylvania, 240 S 40th St., \\ Philadelphia, PA 19104, USA; lifinoti@msn.com \\ 4 Department of Implantology, University of Santo Amaro, Professor Enéas de Siqueira Neto, St., 340, \\ Santo Amaro CEP 04829-300, São Paulo, Brazil; yeon_jungkim@yahoo.com.br \\ 5 Department of Medical Genetics, University of Campinas-UNICAMP, Tessália Vieira de Camargo St., \\ 126 Campinas CEP 13083-887, São Paulo, Brazil; rsecolin@gmail.com \\ 6 Department of Pharmacology, Ribeirão Preto Medical School, University of São Paulo, Bandeirantes Avenue, \\ 3900, Ribeirão Preto CEP 14.049-900, São Paulo, Brazil; marcelofm@pq.cnpq.br (M.F.M.); \\ tanus@fmrp.usp.br (J.E.T.-S.) \\ * Correspondence: raquel@foar.unesp.br
}

Academic Editor: Irmgard Tegeder

Received: 1 March 2017; Accepted: 20 May 2017; Published: 15 June 2017

\begin{abstract}
This study aimed to investigate whether the $-1026(\mathrm{~A}>\mathrm{C})(\mathrm{rs} 2779249)$ and $+2087(\mathrm{~A}>\mathrm{G})(2297518)$ polymorphisms in the NOS2 gene were associated with chronic periodontitis (CP) and with salivary levels of nitrite $\left(\mathrm{NO}_{2}{ }^{-}\right)$and/or nitrate + nitrite (NOx). A group of 113 mixed-race patients were subjected to periodontal, genetic, and biochemical evaluations ( $65 \mathrm{CP} / 48$ periodontally healthy subjects). DNA was extracted from oral epithelial cells and used for genotyping by polymerase chain reaction (real-time). Salivary NOx concentrations were determined using an ozone-based chemiluminescence assay. Association of $\mathrm{CP}$ with alleles and genotypes of the $-1026(\mathrm{~A}>\mathrm{C})$ polymorphism was found $\left(X^{2}\right.$ test, $\left.p=0.0075 ; 0.0308\right)$, but this was not maintained after multiple logistic regression, performed to estimate the effect of covariates and polymorphisms in CP. This analysis demonstrated, after correction for multiple comparisons, that only the female gender was significantly associated with CP. Polymorphisms analyzed as haplotypes were not associated with CP. NOx levels were significantly higher in the control group of heterozygous individuals for both polymorphisms. In conclusion, the female gender was significantly associated with $\mathrm{CP}$, and higher levels of salivary NOx were found in control subjects and associated with the heterozygous state of the NOS2 polymorphisms, reinforcing the potential of NO metabolites as markers of periodontitis status.
\end{abstract}

Keywords: genetic polymorphism; chronic periodontitis; nitric oxide; inducible nitric oxide synthase 


\section{Introduction}

Periodontal diseases (PD), including chronic periodontitis (CP), the most common form of destructive PD in adults, are chronic inflammatory diseases demonstrating loss of connective tissue together with alveolar bone [1]. Bacterial infection is a primary cause of PD, but the disease progression in response to bacteria and metabolic products depends on the production of host inflammatory mediators [2,3]. Periodontitis is considered a complex disease, involving various biological pathways [4]. Complex diseases are associated with variations in multiple genes, each of which has a small overall contribution and relative risk for disease process [5]. Evidence for a genetic factor influencing the periodontal condition was obtained in a study enrolling twins [6]. The genetic makeup of an individual affected by PD together with the environmental influence determine the phenotype of the disease [4]. Most genetics research in periodontitis has focused on gene polymorphisms that play a role in immunoregulation, but little is known regarding a key short-lived molecule that plays role in many physiological and pathological processes [7]. This is nitric oxide (NO), which is a gaseous free radical generated from the conversion of L-arginine to L-citrulline by nitric oxide synthases (NOS) [8]. There are three isoforms of NO synthase (NOS): endothelial (eNOS), neuronal (nNOS), and inducible (iNOS) [9].

In regard to the pathogenesis of $\mathrm{CP}$, evaluation of iNOS appears to be the most interesting, since it is expressed almost exclusively under inflammatory stimuli, such as bacterial lipopolysaccharides and proinflammatory cytokines, in a variety of cell types, including macrophages and neutrophils [10]. PD studies have reported increases in iNOS activity, indicating that in the disease process there might be the production and participation of NO [11]. NO mediates cytotoxic action against microbial pathogens [7] and cell-damaging and toxic effects, by forming peroxynitrite in a reaction with superoxide, which contributes to DNA damage as well as protein damage by combining with tyrosine to form nitrotyrosine (NT) [12-14].

An advance in our understanding of NO biology was the recognition of the nitrate-nitrite-NO axis, whereby nitrate (predominantly from dietary sources) could be converted to nitrite, and nitrite could be reduced to NO [15]. As a biomarker, salivary NO level can be utilized as a good indicator of the inflammatory status of the periodontium [16-18]. However, NO metabolites have a very short life, given that direct measurements of $\mathrm{NO}$ from tissues and biological fluids are difficult to perform, but nitrite and nitrate are the relatively stable end products of NO oxidation $[19,20]$. Interestingly, the level of NO biomarker and its end metabolites in saliva have been shown to be of more value in the assessment of periodontal health than their levels in the gingival crevicular fluid (GCF) [21]. However, salivary NO quantitation in patients with $\mathrm{CP}$ has demonstrated conflicting findings. Some studies have found higher levels of NO metabolites in patients with PD in comparison with healthy controls [7,11,22], while others have observed the opposite [23-25].

The production of NO by the activity of iNOS can be influenced by polymorphisms in the iNOS gene (NOS2 gene, OMIM 163730) [26,27]. Both $-1026(\mathrm{~A}>\mathrm{C})$ and $+2087(\mathrm{~A}>\mathrm{G})$ single nucleotide polymorphisms (SNPs) in the NOS2 gene are potentially functional $[12,18,23,28,29]$ and clinically relevant, as they are associated with hypertensive disorders [29-32], migraine with aura [26], and malignant neoplasias [33,34].

When different SNPs are located in close physical proximity to each other on the chromosome and are inherited in blocks without recombination between parental chromosomes, they are called haplotypes [35]. The -1026(A>C)(rs2779249) and +2087(A>G)(2297518) SNPs in the NOS2 gene were previously investigated as haplotypes in Brazilian [26] and Finnish populations [32]. Haplotypes are more powerful for detecting susceptibility alleles than individual polymorphisms; hence, in disease-association studies, they may give more conclusive results [35].

Because there is only one previous study investigating the association of the above-mentioned SNPs in the NOS2 gene with CP [36], and considering that salivary NO levels in patients with $\mathrm{CP}$ remain controversial, we investigated in the present study the possibility of an association of 
susceptibility to CP with SNPs in the NOS2 gene and its haplotypes and whether these patients' genetic carriage could be related to salivary levels of nitrite $\left(\mathrm{NO}_{2}{ }^{-}\right)$and /or nitrate + nitrite (NOx).

\section{Results}

The power calculation we performed showed that a sample size of 113 individuals was large enough to detect a significant association between $\mathrm{CP}$ and the studied genetic polymorphisms, with an $\alpha$-value of $0.025, \mathrm{OR}=2.65$, and a power of $94 \%$.

Table 1 summarizes demographic data on the mixed-race subjects, given our Brazilian multiethnic population. Comparing the two groups under investigation, there was similarity regarding mean age and gender $(p>0.05)$. There was a higher proportion of smokers in the CP group than in the control group, leading to a slight $(p<0.0465)$ but significant difference between the groups. Considering smoking habits by gender, although there was a higher percentage of female smokers in the CP group, the Fisher's exact test demonstrated no association of these characteristics with CP $(p=0.6894)$.

Table 1. Demographic characteristics of the study participants.

\begin{tabular}{|c|c|c|c|c|}
\hline \multirow{2}{*}{ Characteristics } & Control & Chronic Periodontitis & Total & \multirow{2}{*}{$p *$} \\
\hline & $(n=48)$ & $(n=65)$ & $(n=113)$ & \\
\hline Age (Mean \pm SD) & $35.74( \pm 8.08)$ & $41.84( \pm 8.43)$ & $39.18( \pm 8.75)$ & 0.1268 \\
\hline \multicolumn{5}{|l|}{ Gender (\%) } \\
\hline Female & $23(47.92 \%)$ & $38(58.46 \%)$ & $61(53.98 \%)$ & 0.3572 \\
\hline Male & $25(52.08 \%)$ & $27(41.54 \%)$ & $52(46.02 \%)$ & \\
\hline \multicolumn{5}{|l|}{ Smoking habits (\%) } \\
\hline Smokers & $8(16.66 \%)$ & $23(35.40 \%)$ & $31(27.43 \%)$ & 0.0465 \\
\hline Nonsmokers & $40(83.33 \%)$ & $42(64.60 \%)$ & $82(72.57 \%)$ & \\
\hline \multicolumn{5}{|c|}{ Smoking habits by gender (\%) } \\
\hline & Female $4(50.0 \%)$ & Female $14(60.9 \%)$ & Female 18 (58.0\%) & 0.6894 \\
\hline Smokers & Male $4(50.0 \%)$ & Male $9(39.1 \%)$ & Male $13(41.9 \%)$ & \\
\hline Nonsmolor & Female $19(47.5 \%)$ & Female $24(57.1 \%)$ & Female 43 (52.4\%) & 0.5073 \\
\hline Nonsmokers & Male 21 (52.5\%) & Male $18(42.9 \%)$ & Male $39(47.6 \%)$ & \\
\hline
\end{tabular}

$p^{*}=$ comparison between control and chronic periodontitis groups. $\mathrm{SD}=$ standard deviation.

Table 2 showed that allele and genotype frequencies of the $-1026(\mathrm{~A}>\mathrm{C})$ SNP in the NOS2 gene were significantly different between control and disease groups. For each studied group, the genotype distributions of each SNP were consistent with the assumption of Hardy-Weinberg equilibrium. The AC genotype of the $-1026 \mathrm{SNP}$ was more frequent in the CP group $(41.5 \%, p=0.0308)$ than in the control group. When we combined the AC and AA genotypes, we found that individuals carrying these genotypes were 2.44 times more susceptible to developing $\mathrm{CP}(p=0.0341, \mathrm{OR}=2.44 ; 95 \% \mathrm{CI}=1.13-5.24$, Table 2). The $+2087(\mathrm{~A}>\mathrm{G})$ SNP in the NOS2 gene demonstrated no significant findings.

Table 3 shows the results of multivariate analysis, which was performed to more accurately evaluate the strength of any association and to eliminate the distortion caused by confounding effects. Multiple logistic regression analysis demonstrated that the $-1026(A>C)$ SNP lost its significant association with CP after we adjusted for covariates (Table 3). The multiple logistic regression analysis demonstrated that gender and smoking habits were associated with CP (nominal $p=0.0004$ ). However, after we adjusted for covariates, only gender maintained its significance as a confounding factor in the development of CP (corrected $p=0.0036$, Table 3).

The haplotypes formed by the $-1026(\mathrm{~A}>\mathrm{C})$ and $+2087(\mathrm{~A}>\mathrm{G})$ SNPs showed a similar distribution between the control and $\mathrm{CP}$ groups. The most frequent haplotype in the controls was $-1026(\mathrm{C})$ $+2087(\mathrm{G})$ in homozygotes $(\mathrm{CG} / \mathrm{CG}=43.8 \%$ ), followed by the two heterozygous haplotypes $\mathrm{AG} / \mathrm{CG}=22.9 \%$ and $\mathrm{CA} / \mathrm{CG}=16.7 \%$. 
Table 2. Allele and genotype frequencies of the investigated SNPs in the NOS2A gene.

\begin{tabular}{|c|c|c|c|}
\hline SNP & Control (\%) & Chronic Periodontitis (\%) & $p$ \\
\hline \multicolumn{4}{|c|}{$-1026(\mathrm{~A}>\mathrm{C}) \mathrm{rs} 2779249$} \\
\hline Allele & $n=96$ & $n=130$ & \\
\hline A & $22(22.92 \%)$ & $53(40.77 \%)$ & 0.0075 \\
\hline \multirow[t]{2}{*}{ C } & $74(77.08 \%)$ & $77(59.23 \%)$ & \\
\hline & $\mathrm{OR}=2.3$ & CI $(95 \%)=1.28-4.17$ & \\
\hline Genotype & $n=48$ & $n=65$ & \\
\hline AA & $3(6.3 \%)$ & $13(20.0 \%)$ & \\
\hline $\mathrm{AC}$ & $16(33.3 \%)$ & $27(41.5 \%)$ & 0.0308 \\
\hline $\mathrm{CC}$ & $29(60.4 \%)$ & $25(38.5 \%)$ & \\
\hline H-W Equilibrium & $p=0.6954$ & $p=0.2593$ & \\
\hline $\mathrm{AA}+\mathrm{AC}$ & $19(39.58 \%)$ & $40(61.54 \%)$ & 0.0341 \\
\hline \multirow[t]{2}{*}{$\mathrm{CC}$} & $29(60.420 \%)$ & $25(38.46 \%)$ & \\
\hline & $\mathrm{OR}=2.44$ & $\mathrm{CI}(95 \%)=1.13-5.24$ & \\
\hline \multicolumn{4}{|c|}{$+2087(\mathrm{~A}>\mathrm{G}) \mathrm{rs} 2297518$} \\
\hline Allele & $n=96$ & $n=130$ & \\
\hline A & $15(15.6 \%)$ & $20(15.4 \%)$ & 0.8913 \\
\hline G & $81(84.4 \%)$ & $110(84.6 \%)$ & \\
\hline Genotype & $n=48$ & $n=65$ & \\
\hline $\mathrm{AA}$ & $1(2.1 \%)$ & $2(3.1 \%)$ & \\
\hline AG & $13(27.1 \%)$ & $16(24.6 \%)$ & 0.9155 \\
\hline GG & $34(70.8 \%)$ & $47(72.3 \%)$ & \\
\hline H-W Equilibrium & $p=0.8507$ & $p=0.6601$ & \\
\hline
\end{tabular}

Table 3. Logistic regression results of the analysis.

\begin{tabular}{ccccc}
\hline \multirow{2}{*}{ Covariate } & & OR (95\% CI) & Nominal & Corrected \\
\cline { 4 - 5 } & & & 0.0485 & 0.4365 \\
Age & & $1.08(1.0-1.18)$ & 0.9873 & 1.0000 \\
Nitrite concentration & & $1.00(0.98-1.02)$ & 0.1825 & 1.0000 \\
NOx concentration & Male & Reference category & - & \\
Gender & Female & $8.35(2.23-31.27)$ & 0.0004 & $0.0036^{*}$ \\
& Nonsmokers & Reference category & - & \\
Smoking Habits & Smokers & $4.35(1.1-17.22)$ & 0.0242 & 0.2178 \\
SNP -1026 & CC & Reference category & - & \\
& AC & $2.99(0.77-11.53)$ & 0.1023 & 0.9207 \\
& AA & $5.03(0.92-27.57)$ & 0.0428 & 0.3852 \\
SNP +2087 & C & Reference category & - & \\
& A & $2.95(0.91-9.58)$ & 0.0653 & 0.5877 \\
& AA & Reference category & - & \\
& AG & $2.84(0.09-89.14)$ & 0.4797 & 1.0000 \\
& GG & $7.01(0.21-228.71)$ & 0.1860 & 1.0000 \\
& A & Reference category & - & \\
& G & $2.70(0.66-11.01)$ & 0.1527 & 1.0000 \\
\hline
\end{tabular}

$\mathrm{OR}=$ odds ratio; $\mathrm{CI}=$ confidence interval. ${ }^{*} p$-value which maintained statistically significant after Bonferroni's correction.

Table 4 shows a significantly higher concentration of NOx (nitrate + nitrite) in the control group than in the CP group. Moreover, we observed that heterozygous individuals for each investigated SNP produced significantly higher concentrations of NOx in the control group when compared with the CP group. 
Table 4. Salivary NOx and Nitrite concentrations comparisons between Control and CP groups

\begin{tabular}{|c|c|c|c|c|c|c|}
\hline \multirow[t]{2}{*}{ Mensuration } & \multicolumn{2}{|c|}{$\operatorname{NOx}(\mu \mathrm{M})$} & \multicolumn{4}{|c|}{ Nitrite (nM) } \\
\hline & Control & $\mathrm{CP}$ & $p$-Value * & Control & $\mathrm{CP}$ & $p$-Value \\
\hline & $(n=48)$ & $(n=65)$ & & $(n=48)$ & $(n=65)$ & \\
\hline Mean & 52.19 & 26.52 & & 36.78 & 30.41 & \\
\hline Standard Deviation & \pm 57.27 & \pm 33.76 & & \pm 39.13 & \pm 35.68 & \\
\hline Median (Min-Max) & $27(0-200)$ & $12(0-160)$ & 0.009 & $19(2-146)$ & $18(0-150)$ & 0.368 \\
\hline$-1026(\mathrm{~A}>\mathrm{C}) \mathrm{rs} 2779249$ & \multicolumn{2}{|c|}{ Median (Min-Max) } & \multicolumn{4}{|c|}{ Median (Min-Max) } \\
\hline $\mathrm{AA}$ & $6(5-14)$ & $7(0-83)$ & 0.78 & $30(19-135)$ & $22(0-135)$ & 0.42 \\
\hline $\mathrm{AC}$ & $35(5-193)$ & $14(0-160)$ & 0.01 & $24(4-122)$ & $18(0-150)$ & 0.13 \\
\hline $\mathrm{CC}$ & $27(0-200)$ & $16(1-75)$ & 0.37 & $17(2-146)$ & $19(1-144)$ & 0.98 \\
\hline$p$-value \# & 0.11 & 0.67 & & 0.23 & 0.69 & \\
\hline$+2087(\mathrm{~A}>\mathrm{G}) \mathrm{rs} 2297518$ & \multicolumn{2}{|c|}{ Median (Min-Max) } & \multicolumn{4}{|c|}{ Median (Min-Max) } \\
\hline AA & 22 & $28.5(0-57)$ & 1.00 & 14 & $35.5(9-62)$ & 1.00 \\
\hline AG & $38(6-200)$ & $6.5(0-55)$ & 0.004 & $30(3-146)$ & $15.5(1-135)$ & 0.13 \\
\hline GG & $27(0-170)$ & $16(0-160)$ & 0.12 & $19(2-131)$ & $20(0-150)$ & 0.88 \\
\hline$p$-value $\#$ & 0.31 & 0.07 & & 0.45 & 0.49 & \\
\hline
\end{tabular}

$\mathrm{NOx}=$ nitrate + nitrite, Shapiro-Wilk test for normality evaluation (showing non-parametric data). Min = Minimum, Max $=$ Maximum), $p$-value ${ }^{*}=$ comparison between Control and CP (Mann-Whitney test), $p$-value ${ }^{\#}=$ comparison among genotypes into the Control or $\mathrm{CP}$ groups (Kruskal-Wallis test).

\section{Discussion}

This is the first study, to our knowledge, that investigated the $-1026(A>C)$ and $+2087(A>G)$ SNPs in the NOS2 gene, as well as their haplotypes, and NO production in patients with CP. The NOS2 haplotypes were not associated with CP in this studied Brazilian population. Moreover, any significant association of the +2087 SNP with CP was verified in our southeastern Brazilian population. However, in a northeastern Brazilian population, the $+2087(\mathrm{GG})$ genotype was recently associated with protection against the development of PD [36]. Contrasting results for a SNP association in case-control studies considering different populations are very common, mainly because of differences in the genetic carriage (ethnicity) or in the study design [37].

Regarding the $-1026 \mathrm{SNP}$, we found that individuals carrying the (AC) or (AA) genotypes were more susceptible to CP. However, similar to other studies [36,38], this genetic association was not maintained after the adjustments for covariates in the multiple logistic regression analysis. Multiple logistic regressions were used here to evaluate the influence of common (and other potential) covariates, in the association of each NOS2 SNP with CP. These multiple comparisons revealed that only the female gender (after apply the Bonferroni's correction) was significantly associated with CP. Thus, in this population, a factor (gender) other than genetic background was more powerful in predisposition to $\mathrm{CP}$. Gender is a well-known risk factor for periodontitis, and the literature presents epidemiologic studies showing higher prevalence and severity of destructive PD in men than in women, even after adjusting for behavioral and environmental factors [39-41]. The effect of gender on PD can be attributed to the differences in gene expression and immune cell functioning modulated by sex steroid hormones or to physiological differences between the genders [42].

The levels of NO metabolites were verified to vary depending on the gender, usually being higher in males than in females [43,44]. Andrukhov et al., 2013 [45] observed that male patients with periodontitis exhibited significantly lower salivary $\mathrm{NO}_{2}$ and serum $\mathrm{NOx}$ levels. This data suggests that gender might influence the NO production in periodontitis. Interestingly, Skaleric et al., 2006 [46] and Han et al., 2013 [18] observed a positive link between NO and periodontitis, which was more pronounced in females.

An increasing number of studies have investigated levels of nitrite and nitrate in saliva as periodontal disease biomarkers [16-18,23]. Higher nitrite concentrations were found in whole saliva of periodontally healthy subjects in comparison with PD patients, and this situation remained unchanged after periodontal treatment [23]. In the present study, we demonstrated higher salivary NOx concentrations in the control group than in the periodontitis group, which is in agreement with 
other studies [23-25,45]. Conversely, some studies have observed the opposite; i.e., lower salivary NO levels in the healthy group in comparison with the periodontitis group $[7,11,18,22]$. These contradictory results might be explained by the diverse methods used to quantify $\mathrm{NO}$, their sensitivities [23], the unknown NO stability in saliva, an insufficient number of patients, and different clinical parameters used to classify patients affected by PD [37].

Interestingly, we also observed a significantly higher number of healthy individuals who were heterozygous for the $-1026(\mathrm{~A}>\mathrm{C})(\mathrm{rs} 2779249)$ and $+2087(\mathrm{~A}>\mathrm{G})(\mathrm{rs} 2297518)$ SNPs producing higher levels of NOx (Table 4). We speculate that the observed higher salivary NOx concentrations produced by heterozygous individuals in the control group (Table 4) reflects a level of NO production that is sufficient to eliminate periodontal infection by periodontopathogens, given the antimicrobial activity of NO [7]. Ozer et al., 2011 [24] speculated that a decrease in salivary NO levels in patients with periodontitis compared with healthy individuals may lead to a reduction in the antibacterial properties of saliva, increasing the susceptibility of periodontal tissues to periodontopathogens [24,47]. The same authors [24] highlighted that the saliva of patients with periodontitis did not stimulate, but rather depressed NO synthesis in polymorphonuclear leukocytes (PMNL), whereas the saliva of healthy individuals stimulated NO synthesis [48]. Conversely, it is known that excessively high amounts of locally produced NO exceed the cytotoxic action against microbial pathogens and elicit proinflammatory molecules, unbalancing the immune response equilibrium and leading to periodontal tissue destruction [7]. Ozer et al., 2011 [24] mentioned that, when locally produced in high concentrations, NO may act as both a cytotoxic molecule against invading pathogens and against adjacent tissue cells, thus being related to both beneficial and harmful effects [49], and we entirely agree with them. Finally, the same authors [24] concluded that lower and higher concentrations of $\mathrm{NO}$ can initiate destruction in periodontal tissues, yet a threshold NO level might be required for the remodeling of periodontal tissues.

Indeed, although the investigated SNPs in the NOS2 gene were demonstrated as functional $[23,27,45]$, the exact molecular mechanisms of their action in the modulation of NO metabolites remain unknown. As suggested by Wang et al., 2013 [28] besides the SNPs investigated here, we cannot exclude the possibility of the presence of other functional polymorphisms in linkage disequilibrium (LD) with an investigated SNP being responsible for the genotype-dependent differences in iNOS activity. Further studies are needed to identify polymorphisms in this region and clarify which polymorphism(s) may possess the functional consequence(s) for the genotype-dependent differences in iNOS activity (e.g., NO levels), and provide mechanistic plausibility for the observed association between NOS2 and susceptibility to CP. Moreover, other genes-such as the endothelial nitric synthase (eNOS), which also have polymorphisms-could potentially influence NO levels (even though NO production by eNOS is significantly lower than by iNOS). Indeed, other genes, mechanisms, and pathways could influence salivary NOx production and could be involved in CP development. Therefore, more studies are necessary to elucidate the role of different genes in the synthesis of NO (and its concentration in saliva) in the context of CP.

In addition, other factors could also be influencing the salivary NO metabolites levels: physiological variables, hormones, salivary flow rate, and environmental exposures, such as diet since nitrite and nitrate are present in preserved foods and in green leafy vegetables [9]. Ingested nitrate is absorbed in the stomach and intestines and secreted in concentrated levels in the salivary glands [50]. This concentrated nitrate is reduced to nitrite via facultative anaerobic bacteria in the oral cavity [51]. Unfortunately, knowledge is lacking regarding the exact mechanisms of NO synthesis and action in the periodontium and saliva.

Unfortunately, as a limitation of our study, we did not measure the salivary flow rate of the participants. Although it could have a potential effect on the detected salivary NOx levels, we hypothesize that the NOx concentrations found here were related to the immunological function that contributes to periodontal health. Regarding to the number of patients investigated here, 113 patients demonstrated sufficient power. A previous genetic study of haplotypes formed by the SNPs rs 2779249 
and rs2297518 [26] demonstrated a high $\mathrm{OR}$ value ( $\mathrm{OR}=2.65,95 \% \mathrm{CI}=1.34-5.22)$. Therefore, we could assume that these SNPs have a large effect, and evidence of a genetic association could be detected with a smaller number of individuals. Nevertheless, further studies with larger sample and ethnically different populations, as well as meta-analysis approaches, are needed to better evaluate the potential association of polymorphisms in the NOS2 gene and its influence on NO production in the development of periodontal disease.

\section{Methodology}

\subsection{Selection of Subjects}

This study involved individuals from the State of São Paulo in the southeastern region of Brazil. A total of 113 unrelated subjects, all with similar socio-economic status, were recruited from the patient pool of the School of Dentistry at Araraquara, São Paulo State University (UNESP), from November 2004 to May 2007. The study was approved by the Committee for Ethical Affairs of the São Paulo State University (Protocol number 57/04). All volunteers were informed of the aims and methods of this study, and all gave their written consent [35].

All subjects had to be in good general health, and the exclusion criteria were as follows: use of prophylactic antibiotics, chronic usage of anti-inflammatory drugs, current pregnancy, ongoing orthodontic therapy, and self-declared history of diseases that influence the immune system, diabetes mellitus, HIV infection, or immunosuppressive chemotherapy [35]. Information on smoking status was obtained using a self-reporting questionnaire. Smoking status was assessed, and subjects were classified as "smokers" or "nonsmokers", according to Kornman et al., 1997 [48]. Smokers were current smokers, and nonsmokers were subjects who had never smoked or who had not smoked within the last five years. Each subject was examined by one of two calibrated periodontists (YJK and ACV) who carried out the periodontal examinations throughout the study period (weighted kappa $=0.74$, considering the probing depth [PD]). The following clinical signs and parameters were assessed at six sites around each tooth: PD (as the distance from the gingival margin to the base of the periodontal pocket) and clinical attachment level (CAL, as the distance from the cement-enamel junction to the base of the periodontal pocket) measured to the nearest millimeter by a periodontal probe with Williams markings (Trinity-Campo Mourão, Brazil), and bleeding on probing (BOP), registered as present or absent, as a percentage of the total number of sites. These measurements were made in millimeters and were rounded down to the nearest whole millimeter. All fully erupted teeth, except third molars and retained roots, were examined. The periodontal diagnosis of subjects was established on the basis of clinical criteria, which categorized subjects into two groups, similar to previously published studies [35,52-54]:

- Control group $(n=48)$ : subjects exhibiting no sites with CAL and PPD $\geq 3 \mathrm{~mm}$ and BOP.

- Periodontitis group $(n=65)$ : subjects exhibiting one or more sites with CAL and PPD $\geq 3 \mathrm{~mm}$ and BOP.

Statistical power was calculated according to the strength of the single nucleotide polymorphism (SNP)-associated genetic disease in terms of the odds ratio (OR), the statistical test to be used, and the number of polymorphisms to be analyzed in the gene [55]. To verify the statistical power of our sample to detect genetic associations, we used the $G^{*}$ Power 3 software [56] with the following parameters: logistic regression; post hoc; two-tail; odds ratio $(\mathrm{OR})=2.65$ [26] $\alpha$ error probability $=0.025$ (because we investigated 2 SNPs) [26].

\subsection{Analysis of Genetic Polymorphisms}

Buccal epithelial cells from the subjects were obtained using $3 \mathrm{~mL}$ of $3 \%$ glucose mouthwash for $2 \mathrm{~min}$. DNA was extracted with sequential phenol/chloroform/isoamyl alcohol (25:24:1) solution and precipitated with salt ethanol solution [35]. The analysis of genetic polymorphisms was performed 
using real-time polymerase chain reaction (qPCR). The $-1026(\mathrm{~A}>\mathrm{C})(\mathrm{rs} 2779249)$ and $+2087(\mathrm{~A}>\mathrm{G})$ (rs2297518) SNPs in the NOS2 gene were genotyped using predesigned TaqMan SNP Genotyping Assays (Applied Biosystems, Foster City, CA, USA). DNA amplification was carried out in a $13 \mu \mathrm{L}$ volume containing $20 \mathrm{ng}$ genomic DNA, $6.25 \mu \mathrm{L}$ of $2 \times$ Master Mix (Applied Biosystems), $0.63 \mu \mathrm{L}$ $20 \times$ TaqMan Assay Mix (Applied Biosystems), and $4.63 \mu \mathrm{L}$ of RNA/DNAase-free water (Applied Biosystems). The amplifications in 96-well plates were made in a 7500 Real Time PCR System (Applied Biosystems, Foster City, CA, USA). Subsequently, end-point fluorescence was determined using 7500 System Sequence Detection Software (Applied Biosystems, Foster City, CA, USA).

\subsection{Measurement of Salivary NOx Concentration}

The participants were asked not to rinse their mouth, brush their teeth, eat food, or drink liquids for $2 \mathrm{~h}$ before the time of clinic attendance (before the periodontal examination). Approximately 1 $\mathrm{mL}$ of non-stimulated saliva was collected from each patient and maintained on ice, until storage at $-80^{\circ} \mathrm{C}$.

Saliva aliquots were analyzed in triplicate for their nitrite $\left(\mathrm{NO}_{2}{ }^{-}\right)$and / or nitrate + nitrite (NOx) contents using an ozone-based chemiluminescence assay (NO analyzer, Sievers Model 280, Boulder, CO, USA). Details of the method were previously described $[57,58]$.

\subsection{Data Analysis}

We used the chi-squared test to verify differences between cases and controls for gender and smoking habits, whereas the mean age difference between groups was evaluated using a Student's $t$-test. A Fisher's exact test was used to compare smoking habits by gender between control and $\mathrm{CP}$ groups. The distribution of each polymorphism in each group was tested for Hardy-Weinberg equilibrium. The haplotype analysis was made by the ARLEQUIN program ${ }^{32}$. Differences between groups in the allelic and genotypic frequencies of the polymorphisms and haplotypes were analyzed by the $X^{2}$ test and odds ratio using the GraphPad InStat software, version 3.05 (Graph Pad Software Inc., San Diego, CA, USA). A multivariate logistic regression model was performed to estimate the effect of the covariates (age, nitrite, NOx, gender, smoking habits, and polymorphisms) and the SNPs in the phenotype, by R statistical software (https:/ / www.r-project.org/). For the NOx concentration, the Shapiro-Wilk test for normality evaluation was performed, followed by the Kruskal-Wallis or Mann-Whitney tests for comparison between Control and CP groups. All tests were performed at a significance level of $5 \%$, and the Bonferroni correction for multiple tests was applied.

\section{Conclusions}

After multiple logistic regression analysis, we concluded that neither the $-1026(\mathrm{~A}>\mathrm{C})$ and $+2087(\mathrm{~A}>\mathrm{G}) \mathrm{SNPs}$ in the NOS2 gene, nor the haplotypes, but only gender were associated with CP. Moreover, there was association of the heterozygous -1026(AC) and +2087(AG) SNPs with a significantly higher concentration of NOx in Brazilian individuals not affected by CP. These results contribute to the investigation of the usefulness of salivary NO metabolites as markers of periodontitis status. More ambitiously, in the future, these markers can be associated with the patient's genetic carriage, identifying individuals more susceptible to $\mathrm{CP}$ who can be benefit from preventive treatments.

Acknowledgments: This study was supported by FAPESP grants (03/10424-0 and 05/03231-7).

Author Contributions: Raquel M. Scarel-Caminaga conceived the project, obtained financial support, carried out the statistical analysis, and drafted the manuscript; Flávia F. Cera genotyped all patients and helped with genetic analysis; Suzane C. Pigossi helped with the genotyping methodology and analysis and drafted the manuscript; Livia S. Finoti helped with the genotyping analysis and with statistical analysis; Yeon J. Kim executed periodontal examination, selection of patients, samples collection, and DNA extraction; Aline C. Viana executed periodontal examination, selection of patients, samples collection, and DNA extraction; Rodrigo Secolin carried out the genetic and statistical analysis; Marcelo F. Montenegro carried out all the salivary NOx concentrations analysis and drafted the manuscript; José E. Tanus-Santos study design and carried out the NOx analysis; Silvana R. P. Orrico 
supervised periodontal clinical examination and selection of patients; Joni A. Cirelli supervised periodontal clinical examination and selection of patients and drafted the manuscript.

Conflicts of Interest: The authors declare no conflict of interest.

\section{References}

1. American Academy of Periodontology. Parameter on chronic periodontitis with slight to moderate loss of periodontal support. J. Periodontol. 2000, 71, 853-855.

2. Page, R.C. The role of inflammatory mediators in the pathogenesis of periodontal disease. J. Periodontal Res. 1991, 26, 230-242. [CrossRef] [PubMed]

3. Socransky, S.S.; Haffajee, A.D.; Smith, C.; Duff, G.W. Microbiological parameters associated with IL-1 gene polymorphisms in periodontitis patients. J. Clin. Periodontol. 2000, 27, 810-818. [CrossRef] [PubMed]

4. Yoshie, H.; Kobayashi, T.; Tai, H.; Galicia, J.C. The role of genetic polymorphisms in periodontitis. Periodontology 2000 2007, 43, 102-132. [CrossRef] [PubMed]

5. Laine, M.L.; Crielaard, W.; Loos, B.G. Genetic susceptibility to periodontitis. Periodontology 2000 2012, 58, 37-68. [CrossRef] [PubMed]

6. Michalowicz, B.S.; Diehl, S.R.; Gunsolley, J.C.; Sparks, B.S.; Brooks, C.N.; Koertge, T.E.; Califano, J.V.; Burmeister, J.A.; Schenkein, H.A. Evidence of a substantial genetic basis for risk of adult periodontitis. J. Periodontol. 2000, 71, 1699-1707. [CrossRef] [PubMed]

7. Kendall, H.K.; Marshall, R.I.; Bartold, P.M. Nitric oxide and tissue destruction. Oral Dis. 2001, 7, 2-10. [CrossRef] [PubMed]

8. Jenkins, D.C.; Charles, I.G.; Thomsen, L.L.; Moss, D.W.; Holmes, L.S.; Baylis, S.A.; Rhodes, P.; Westmore, K.; Emson, P.C.; Moncada, S. Roles of nitric oxide in tumor growth. Proc. Natl. Acad. Sci. USA 1995, 92, 4392-4396. [CrossRef] [PubMed]

9. Lundberg, J.O. Cardiovascular prevention by dietary nitrate and nitrite. Am. J. Physiol. Circ. Physiol. 2009, 296, H1221-H1223. [CrossRef] [PubMed]

10. Shaker, O.; Ghallab, N.A.; Hamdy, E.; Sayed, S. Inducible nitric oxide synthase (iNOS) in gingival tissues of chronic periodontitis with and without diabetes: Immunohistochemistry and RT-PCR study. Arch. Oral Biol. 2013, 58, 1397-1406. [CrossRef] [PubMed]

11. Shapiro, L.F.; Freeman, K. The relationship between estrogen, estrogen receptors and periodontal disease in adult women: A review of the literature. N. Y. State Dent. J. 2014, 80, 30-34. [PubMed]

12. Dhillon, S.S.; Mastropaolo, L.A.; Murchie, R.; Griffiths, C.; Thoni, C.; Elkadri, A.; Xu, W.; Mack, A.; Walters, T.; Guo, C.; et al. Higher activity of the inducible nitric oxide synthase contributes to very early onset inflammatory bowel disease. Clin. Trans. Gastroenterol. 2014, 5, e46. [CrossRef] [PubMed]

13. Cross, R.K.; Wilson, K.T. Nitric oxide in inflammatory bowel disease. Inflamm. Bowel Dis. 2003, 9, $179-189$. [CrossRef] [PubMed]

14. McCafferty, D.M. Peroxynitrite and inflammatory bowel disease. Gut 2000, 46, 436-439. [CrossRef] [PubMed]

15. Waltz, P.; Escobar, D.; Botero, A.M.; Zuckerbraun, B.S. Nitrate/Nitrite as Critical Mediators to Limit Oxidative Injury and Inflammation. Antioxid. Redox Signal. 2015, 23, 328-339. [CrossRef] [PubMed]

16. Sukuroglu, E.; Guncu, G.N.; Kilinc, K.; Caglayan, F. Using Salivary Nitrite and Nitrate Levels as a Biomarker for Drug-Induced Gingival Overgrowth. Front. Cell. Infect. Microbiol. 2015, 1, 87. [CrossRef] [PubMed]

17. Parwani, S.R.; Chitnis, P.J.; Parwani, R.N. Salivary nitric oxide levels in inflammatory periodontal disease -A case-control and interventional study. Int. J. Dent. Hyg. 2012, 10, 67-73. [CrossRef] [PubMed]

18. Han, D.H.; Kim, M.S.; Shin, H.S.; Park, K.P.; Kim, H.D. Association between periodontitis and salivary nitric oxide metabolites among community elderly Koreans. J. Periodontol. 2013, 84, 776-784. [CrossRef] [PubMed]

19. Lappin, D.F.; Kjeldsen, M.; Sander, L.; Kinane, D.F. Inducible nitric oxide synthase expression in periodontitis. J. Periodontal Res. 2000, 35, 369-373. [CrossRef] [PubMed]

20. Ugar-Cankal, D.; Ozmeric, N. A multifaceted molecule, nitric oxide in oral and periodontal diseases. Clin. Chim. Acta 2006, 366, 90-100. [CrossRef] [PubMed]

21. Poorsattar Bejeh-Mir, A.; Parsian, H.; Akbari Khoram, M.; Ghasemi, N.; Bijani, A.; Khosravi-Samani, M. Diagnostic Role of Salivary and GCF Nitrite, Nitrate and Nitric Oxide to Distinguish Healthy Periodontium from Gingivitis and Periodontitis. Int. J. Mol. Cell. Med. 2014, 3, 138-145. [PubMed] 
22. Reher, V.G.; Zenobio, E.G.; Costa, F.O.; Reher, P.; Soares, R.V. Nitric oxide levels in saliva increase with severity of chronic periodontitis. J. Oral Sci. 2007, 49, 271-276. [CrossRef] [PubMed]

23. Meschiari, C.A.; Zuardi, L.R.; Gomes, V.A.; Costa de Almeida, G.R.; Novaes, A.B., Jr.; Gerlach, R.F.; Marcaccini, A.M. Salivary, blood and plasma nitrite concentrations in periodontal patients and healthy individuals before and after periodontal treatment. Clin. Chim. Acta 2015, 15, 293-296. [CrossRef] [PubMed]

24. Ozer, L.; Elgun, S.; Ozdemir, B.; Pervane, B.; Ozmeric, N. Arginine-nitric oxide-polyamine metabolism in periodontal disease. J. Periodontol. 2011, 82, 320-328. [CrossRef] [PubMed]

25. Aurer, A.; Aleksic, J.; Ivic-Kardum, M.; Aurer, J.; Culo, F. Nitric oxide synthesis is decreased in periodontitis. J. Clin. Periodontol. 2001, 28, 565-568. [CrossRef] [PubMed]

26. De, O.S.M.T.; Goncalves, F.M.; Martins-Oliveira, A.; Speciali, J.G.; Dach, F.; Lacchini, R.; Tanus-Santos, J.E. Inducible nitric oxide synthase haplotype associated with migraine and aura. Mol. Cell. Biochem. 2012, 364, 303-308.

27. Nebel, D.; Bratthall, G.; Ekblad, E.; Norderyd, O.; Nilsson, B.O. Estrogen regulates DNA synthesis in human gingival epithelial cells displaying strong estrogen receptor beta immunoreactivity. J. Periodontal Res. 2011, 46, 622-628. [PubMed]

28. Wang, Z.; Feng, K.; Yue, M.; Lu, X.; Zheng, Q.; Zhang, H.; Zhai, Y.; Li, P.; Yu, L.; Cai, M.; et al. A non-synonymous SNP in the NOS2 associated with septic shock in patients with sepsis in Chinese populations. Hum. Genet. 2013, 132, 337-346. [CrossRef] [PubMed]

29. Fu, L.; Zhao, Y.; Lu, J.; Shi, J.; Li, C.; Liu, H.; Li, Y. Functional single nucleotide polymorphism-1026C/A of inducible nitric oxide synthase gene with increased YY1-binding affinity is associated with hypertension in a Chinese Han population. J. Hypertens. 2009, 27, 991-1000. [CrossRef] [PubMed]

30. Amaral, L.M.; Palei, A.C.; Sandrim, V.C.; Luizon, M.R.; Cavalli, R.C.; Duarte, G.; Tanus-Santos, J.E. Maternal iNOS genetic polymorphisms and hypertensive disorders of pregnancy. J. Hum. Hypertens. 2012, 26, 547-552. [CrossRef] [PubMed]

31. Li, W.; Liu, H.; Fu, L.; Li, D.; Zhao, Y. Identification of Yin Yang 1-interacting partners at -1026C/A in the human iNOS promoter. Arch. Biochem. Biophys. 2010, 498, 119-126. [CrossRef] [PubMed]

32. Nikkari, S.T.; Maatta, K.M.; Kunnas, T.A. Functional Inducible Nitric Oxide Synthase Gene Variants Associate With Hypertension: A Case-Control Study in a Finnish Population-The TAMRISK Study. Medicine 2015, 94, e1958. [CrossRef] [PubMed]

33. Wang, S.S.; Davis, S.; Cerhan, J.R.; Hartge, P.; Severson, R.K.; Cozen, W.; Lan, Q.; Welch, R.; Chanock, S.J.; Rothman, N. Polymorphisms in oxidative stress genes and risk for non-Hodgkin lymphoma. Carcinogenesis 2006, 27, 1828-1834. [CrossRef] [PubMed]

34. Lee, K.M.; Kang, D.; Park, S.K.; Berndt, S.I.; Reding, D.; Chatterjee, N.; Chanock, S.; Huang, W.Y.; Hayes, R.B. Nitric oxide synthase gene polymorphisms and prostate cancer risk. Carcinogenesis 2009, 30, 621-625. [CrossRef] [PubMed]

35. Scarel-Caminaga, R.M.; Kim, Y.J.; Viana, A.C.; Curtis, K.M.; Corbi, S.C.; Sogumo, P.M.; Orrico, S.R.; Cirelli, J.A. Haplotypes in the interleukin 8 gene and their association with chronic periodontitis susceptibility. Biochem. Genet. 2011, 49, 292-302. [CrossRef] [PubMed]

36. Silveira, V.R.S.; Pigossi, S.C.; Scarel-Caminaga, R.M.; Cirelli, J.A.; Rêgo, R.; Nogueira, N.A.P. Analysis of polymorphisms in Interleukin 10, NOS2A, and ESR2 genes in chronic and aggressive periodontitis. Braz. Oral Res. 2016, 30, 105. [CrossRef] [PubMed]

37. Kinane, D.F.; Hart, T.C. Genes and gene polymorphisms associated with periodontal disease. Crit. Rev. Oral Biol. Med. 2003, 14, 430-449. [CrossRef] [PubMed]

38. Scarel-Caminaga, R.M.; Curtis, K.M.; Renzi, R.; Sogumo, P.M.; Anovazzi, G.; Viana, A.C.; Kim, Y.J.; Orrico, S.R.; Cirelli, J.A. Variation in the CXCR1 gene (IL8RA) is not associated with susceptibility to chronic periodontitis. J. Negat. Results Biomed. 2011, 3, 14. [CrossRef] [PubMed]

39. Hyman, J.J.; Reid, B.C. Epidemiologic risk factors for periodontal attachment loss among adults in the United States. J. Clin. Periodontol. 2003, 30, 230-237. [CrossRef] [PubMed]

40. Susin, C.; Dalla Vecchia, C.F.; Oppermann, R.V.; Haugejorden, O.; Albandar, J.M. Periodontal attachment loss in an urban population of Brazilian adults: Effect of demographic, behavioral, and environmental risk indicators. J. Periodontol. 2004, 75, 1033-1041. [CrossRef] [PubMed]

41. Bouchard, P.; Boutouyrie, P.; Mattout, C.; Bourgeois, D. Risk assessment for severe clinical attachment loss in an adult population. J. Periodontol. 2006, 77, 479-489. [CrossRef] [PubMed] 
42. McClelland, E.E.; Smith, J.M. Gender specific differences in the immune response to infection. Arch. Immunol. Ther. Exp. 2011, 59, 203-213. [CrossRef] [PubMed]

43. Watanabe, T.; Akishita, M.; Toba, K.; Kozaki, K.; Eto, M.; Sugimoto, N.; Kiuchi, T.; Hashimoto, M.; Shirakawa, W.; Ouchi, Y. Influence of sex and age on serum nitrite/nitrate concentration in healthy subjects. Clin. Chim. Acta 2000, 301, 169-179. [CrossRef]

44. Ghasemi, A.; Zahedi Asl, S.; Mehrabi, Y.; Saadat, N.; Azizi, F. Serum nitric oxide metabolite levels in a general healthy population: Relation to sex and age. Life Sci. 2008, 83, 326-331. [CrossRef] [PubMed]

45. Andrukhov, O.; Haririan, H.; Bertl, K.; Rausch, W.D.; Bantleon, H.P.; Moritz, A.; Rausch-Fan, X. Nitric oxide production, systemic inflammation and lipid metabolism in periodontitis patients: Possible gender aspect. J. Clin. Periodontol. 2013, 40, 916-923. [CrossRef] [PubMed]

46. Skaleric, U.; Gaspirc, B.; McCartney-Francis, N.; Masera, A.; Wahl, S.M. Proinflammatory and antimicrobial nitric oxide in gingival fluid of diabetic patients with periodontal disease. Infect. Immun. 2006, 74, 7010-7013. [CrossRef] [PubMed]

47. Bodis, S.; Haregewoin, A. Evidence for the release and possible neural regulation of nitric oxide in human saliva. Biochem. Biophys. Res. Commun. 1993, 194, 347-350. [CrossRef] [PubMed]

48. Kornman, K.S.; Crane, A.; Wang, H.Y.; di Giovine, F.S.; Newman, M.G.; Pirk, F.W.; Wilson, T.G., Jr.; Higginbottom, F.L.; Duff, G.W. The interleukin-1 genotype as a severity factor in adult periodontal disease. J. Clin. Periodontol. 1997, 24, 72-77. [CrossRef] [PubMed]

49. Batista, A.C.; Silva, T.A.; Chun, J.H.; Lara, V.S. Nitric oxide synthesis and severity of human periodontal disease. Oral Dis. 2002, 8, 254-260. [CrossRef] [PubMed]

50. Lundberg, J.O; Govoni, M. Inorganic nitrate is a possible source for systemic generation of nitric oxide. Free Radic. Biol. Med. 2004, 37, 395-400. [CrossRef] [PubMed]

51. Eich, R.F.; Li, T.; Lemon, D.D.; Doherty, D.H.; Curry, S.R.; Aitken, J.F.; Mathews, A.J.; Johnson, K.A.; Smith, R.D.; Phillips, G.N., Jr.; et al. Mechanism of NO-induced oxidation of myoglobin and hemoglobin. Biochemistry 1996, 35, 6976-6983. [CrossRef] [PubMed]

52. Kim, Y.J.; Viana, A.C.; Curtis, K.M.; Orrico, S.R.; Cirelli, J.A.; Scarel-Caminaga, R.M. Lack of association of a functional polymorphism in the interleukin 8 gene with susceptibility to periodontitis. DNA Cell Biol. 2009, 28, 185-190. [CrossRef] [PubMed]

53. Kim, Y.J.; Viana, A.C.; Curtis, K.M.; Orrico, S.R.; Cirelli, J.A.; Mendes-Junior, C.T.; Scarel-Caminaga, R.M. Association of haplotypes in the IL8 gene with susceptibility to chronic periodontitis in a Brazilian population. Clin. Chim. Acta 2010, 411, 1264-1268. [CrossRef] [PubMed]

54. Viana, A.C.; Kim, Y.J.; Curtis, K.M.; Renzi, R.; Orrico, S.R.; Cirelli, J.A.; Scarel-Caminaga, R.M. Association of haplotypes in the CXCR2 gene with periodontitis in a Brazilian population. DNA Cell Biol. 2010, 29, 191-200. [CrossRef] [PubMed]

55. De Araujo, T.K.; Secolin, R.; Felix, T.M.; de Souza, L.T.; Fontes, M.I.; Monlleo, I.L.; de Souza, J.; Fett-Conte, A.C.; Ribeiro, E.M.; Xavier, A.C.; et al. A multicentric association study between 39 genes and nonsyndromic cleft lip and palate in a Brazilian population. J. Cranio Maxillofac. Surg. 2016, 44, 16-20. [CrossRef] [PubMed]

56. Faul, F.; Erdfelder, E.; Lang, A.G.; Buchner, A. G*Power 3: A flexible statistical power analysis program for the social, behavioral, and biomedical sciences. Behav. Res. Methods 2007, 39, 175-191. [CrossRef] [PubMed]

57. Metzger, I.F.; Sertorio, J.T.; Tanus-Santos, J.E. Relationship between systemic nitric oxide metabolites and cyclic GMP in healthy male volunteers. Acta Physiol. 2006, 188, 123-127. [CrossRef] [PubMed]

58. Sandrim, V.C.; Palei, A.C.; Sertorio, J.T.; Cavalli, R.C.; Duarte, G.; Tanus-Santos, J.E. Effects of eNOS polymorphisms on nitric oxide formation in healthy pregnancy and in pre-eclampsia. Mol. Hum. Reprod. 2010, 16, 506-510. [CrossRef] [PubMed]

(C) 2017 by the authors. Licensee MDPI, Basel, Switzerland. This article is an open access article distributed under the terms and conditions of the Creative Commons Attribution (CC BY) license (http:/ / creativecommons.org/licenses/by/4.0/). 